\title{
Social and financial feasibility of the development of rural tourism and the hospitality industry in the Rostov Region
}

\author{
Lyudmila Kazmina ${ }^{1, *}$, Valeria Provotorina ${ }^{1}$, Vadim Makarenko ${ }^{1}$, and Antonina Petrenko ${ }^{1}$ \\ ${ }^{1}$ Don State Technical University, Gagarina Sq., 1, Rostov-on-Don, 344003, Russia
}

\begin{abstract}
The article is directed toward the study of social and economic aspects ofrural tourism and the hospitality industry, and toward the analysis of methods of efficiency of their development in the Rostov Region.The study defines rural tourism, considers its development potential in the territory of the Rostov Region, highlights the structure and state of the hospitality industry and demonstrates feasibility of importance and advisability of the development of accommodation places as a component of rural tourism infrastructure in the Rostov Region.
\end{abstract}

\section{Introduction}

The social and economic development of rural tourism and the hospitality industry becomes relevant for the economic growth of the Rostov Region. The formation of the rural tourism industry may have a multiplier effect and thus promote the economic growth of the Don Region in general.The tourism development in rural territories will both bring the tourism industry to the new level and have a positive effect on the development of the regional social and economic sector and provide for additional revenues for state and municipal treasuries.

According to UNWTO, rural tourism makes the top 5 main strategic tourism growth options in the world.In developed European countries, this type of tourism brings about 20$30 \%$ of the total earnings from tourism industry.At that, only $20 \%$ of tourist potential is utilized in Russia.According to the Ministry of Agriculture of the Russian Federation, 11 regions are engaged in the development of rural tourism and the share of this tourism segment is only $2 \%$. There are at least one thousand administrative districts, in the territory of which it is possible to develop rural tourism.Rural tourism is a new sphere for Russia, yet such projects as A Way Home (Leningrad Region), Green House (Altai Mountains), so called B\&B (Baikal Region), Water, Nature and People in Disappearing Landscape, etc. are run in the country.Most of all objects of rural tourism are in the Irkutsk Region - more than 200, in the Kaluga Region and the Altai Territory - 100 in each constituent entity of the Russian Federation. What does afford ground for a potential financial effect of the rural tourism development in Russia?Provided that a comprehensive strategy is implemented including the joint development of agricultural activity and rural tourism, the effect may increase twofold.

\footnotetext{
*Corresponding author: kafedra_tiig@mail.ru
} 
The purpose of the present paper is to analyze the main indicators of the rural tourism and hospitality industry and their impact on the social and economic development of the Don Region.Rural tourism is able to strengthen the attractiveness of territories both as traveler attractions and habitual residence, to make rural recreation an income-generating activity, to involve rural population and to provide urban dwellers with recreation in unpolluted areas, with an insight into local sightseeing attractions, arts and crafts, traditions.Considering prospects of rural tourism in the territory of the Rostov region, it is essential to summarize the experience of foreign countries (Spain, Finland, Austria, Germany, Great Britain, Poland, Belarus), where such touristic projects are successfully run; to increase hospitality bed availability in rural areas, to arrange stylized farmsteads for tourists' accommodation, to teach basic techniques of hospitality and services, laying down hospitality programs, to develop programs of new travel itineraries, and cultural and recreation, newsworthy events for rural regions.

\section{Materials and methods}

At the present stage of the development of the tourism industry, it is necessary to consider global trends, as sooner or later they will have to be considered for strategies and practical activities. Experience of European countries and global trends are vital both in practical activity and research analytics.

Research on rural tourism is a subject matter of studies of T.N. Songkhla, 2013 [1], H.A.M. Shaffril, A. Hamzah, S.Md. Yassin, B.A. Samah, J.L. D’Silva, N. Tiraieyari, M. Muhammad, 2015 [2], G.O. Hossein, H. Alipour, S. Dalir, 2014 [3], F. Leco, J.M. Hernández, A.M. Campón, 2012 [4].

Rural tourism provides a mean to mitigate a negative impact of metropolises on health, to take the mind off the everyday, to have outdoor recreation with a family and children.In the past, the concept of a holiday for the majority meant a trip to "the seaside", to a coastal area, though many people now prefer to spend their time in more tranquil natural surroundings. This change in understanding of "the holiday" has given rise to the concept of "rural tourism" in its current meaning [5].Rural tourism is tourism and recreation, which is closely associated with peasant agriculture, farming, gardening, fishing or any other agricultural business [6].Rural tourism is a sector of the tourism industry targeted at using natural, cultural-historical and other resources and peculiarities of rural settlements for the complex tourist product development. This field of small tourism business is oriented towards tourists' active rest and recreation in villages.Rural tourism is sometimes called "agritourism", "farm tourism" or "green tourism", although agritourism is often regarded as a trend of rural tourism which focuses on tourists' participation in farming activities together with local population of the villages.In this case tourists reside in farmers' houses and for a definite period live according to the local lifestyle [7].

As stated by Lane and Kastenholz, rural tourism has become an umbrella concept encompassing many different specific types of tourism rather than the narrow definition of the past.Rural tourism is regarded as a valid developmental strategy for rural areas in many developed and developing countries. Founded on rural tourism, this developmental strategy was aimed at the growth of agricultural economies while preserving the existing traditional structure [8].However, although this approach to the development of the agricultural economy has become increasingly popular, Lun, Pechlaner, and Volgger emphasize that rural destinations should be careful about possible environmental issues, as well as economic and social problems, when basing their economies on tourism-based diversity [9].Because the rural environment is particularly fragile and sensitive to the development of tourism.Compared to other types of tourism, rural tourism is infant and not the first choice for recreation for most tourists. 
This is due to the problems of organizing rural tourism, formulated in the papers of a number of authors $[10,11]$.Moreover, seasonal fluctuations play an important role; foreign authors mention this problem, in particular R.M. Torres, J.H. Momsen [12]; there are certain problems related to training of qualified personnel $[13,14]$.

The analysis of hotel services market and the prospects for the development of rural tourism in the Rostov region are the subjects of papers of such authors as L.N. Kazmina, V.S. Makarenko, V.V. Provotorina, T.N. Grigorenko G.E. Ekinil, E.M Shevchenko,A.S.Petrenko $[16,17,18,19,20]$.

Tourism industry is one of the most profitable sectors of the world economy and plays an important and sometimes the main role in drawing up the gross domestic product, strengthening the balance of trade, and providing employment opportunities. The impact of tourism on the regional economy may be direct and indirect.A direct impact arises in the process of spending by tourists in the region of residence. Tourist money stays in the region and increases its income, i.e. a chain of "expenses-income-expenses" arises, and so on. In the course of cycling of tourist expenses in the regional economy, an indirect impact, or "multiplier effect" comes into force.Tourist money begins to work for the regional economy at the moment of payment for tourist services. Service providers use this money to pay their employees, who spend it to pay for services, goods, etc. At each stage of the provision of services, tax payments are made to regional treasuries, which subsequently enable representatives of regional authorities to apply funds received forward financing the social sphere of the region.

The rural tourism sector can have a significant synergistic effect, both for related industries and for the social and economic development of rural areas; therefore, a comprehensive procedure for estimation of the performance of this sector based on social and financial feasibility is needed.

Rural means of accommodation serve as a tool for the system of preservation of historical heritage, traditions, traditional crafts, and have a multilateral impact on the surrounding area.In economic terms, rural means of accommodation provide for additional income through self-employment of rural residents, increasing the investment attractiveness of rural areas.

The social role of the development of rural accommodation means is to provide employment opportunities for the population, especially for young people. Work in a rural guest house can be the factor that keeps young people from moving to cities, keeps the population and preserves rural areas.Guest houses based on farms and private farm holdings provide tourists with environmentally friendly products, which are not always available in urban environments. Improvement of houses and surrounding areas enables to preserve the identity of the Russian village and beautifies the surrounding landscape.

The research methodology is based on the application of a comparative analysis method, which made it possible to compare rural accommodation means in the Rostov region for objective estimation of their infrastructure and special aspects of providing basic and additional services. The application of the typification method allowed us to consider the existing accommodation means in rural areas in relation with the special aspects of organization of guest service. The advanced planning method was applied to develop recommendations for improving one of the main components of rural tourism infrastructure - means of accommodation. The method of analysis and synthesis made it possible to study socio-economic phenomena both in parts (analysis) and as a whole (synthesis).The combination of analysis and synthesis provided a systematic approach to complex research objects.Scientific provisions, conclusions and recommendations contained in the article are based on the use of the combined method of logical analysis, economic and statistical method.

\section{Results}


The rural tourism industry is a combination of transport companies, establishments of catering, trade, leisure, excursion services. Accommodation means are the main component of rural tourism infrastructure.At the present stage of the development of the rural tourism industry, there are about 4500 rural accommodation means in Russia, while 3500 are rural guest houses and about 1000 are agrotourist farms. There are about 10,000 other objects of rural tourism (craft houses, handicraft workshops, rural "museums of traditional life", rural routes, places of interest, interactive programs, etc.).

In the Rostov region, there are about 1000 accommodation means, while a significant part, about 700, are urban.Thus, rural accommodation means of various types account for about 300 units, with an average capacity of 15 rooms, an average cost of accommodation per night of 1900 rubles. The total hospitality bed availability in rural hotels is 1,700 rooms, more than 5,000 beds.

This goes to prove the availability of basic infrastructure for the development of rural tourism in the Rostov Region.However, the distribution of accommodation means in rural areas is very unequal.Thus, in 28 rural districts there are less than 5 accommodation means in each; in 11 districts there are up to 12 establishments of the hotel industry, and only in 5 districts this figure exceeds 15 units.

As can be seen from the above figures, the share of rural hospitality industry establishments is $30 \%$ in the Rostov region, while, according to the Federal Service of State Statistics, the population of the region is 4.2 million people, of which $68 \%$ are urban dwellers, $32 \%$ are people living in 390 rural settlements.

For a detailed analysis of the development of rural tourism, districts of the Rostov region with a more developed tourist infrastructure were selected: Ust-Donetsky, Azov and Myasnikovsky. These districts have an advantageous physicogeographical location, a developed transport infrastructure, rich history, and distinctive culture and are distinguished by their proximity to the regional center.A comparative analysis of rural accommodation means in typical areas of the regionis shown in Figures 1, 2.3.

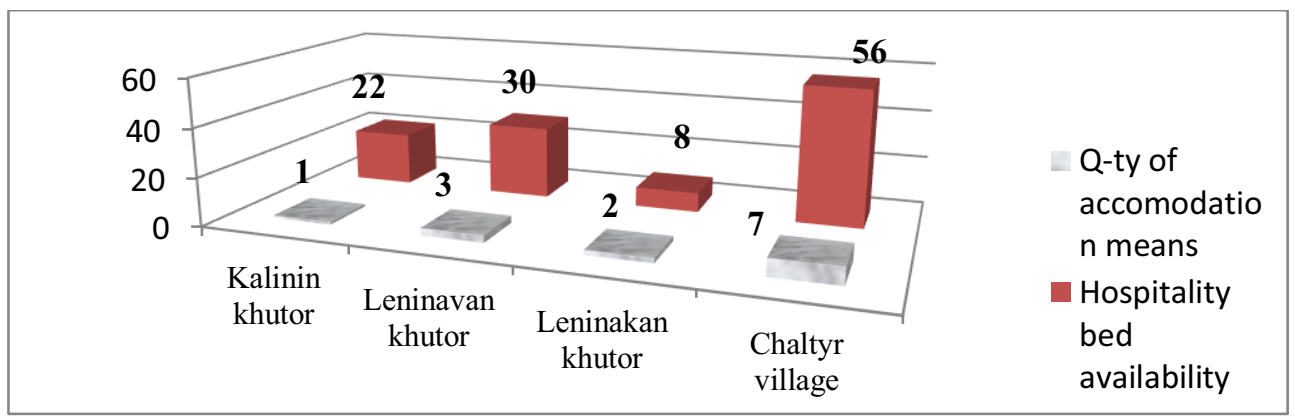

Fig. 1. The main indicators of rural accommodation means in the Myasnikovsky district of the Rostov region

Myasnikovsky district is an administrative unit of the Rostov region, the territory of which is directly adjacent to the regional center - the city of Rostov-on-Don and is rich in architectural monuments, historical places that are of interest to tourists.

The peculiarities of the development of the hotel services market in the Myasnikovsky district of the Rostov region are due to natural and recreational conditions, a convenient location, proximity to a traffic intersection; concentration of a large number of considerably popular catering establishments, which are especially popular as a place for recreation and for holding various-scale celebrations and weddings among consumers of nearby settlements, including a city with a population of more than one million, Rostov-on-Don. One of the largest accommodation means is the Country Club "Khutorok", located in the Leninavankhutor. The hotel of the club is represented by a detached building and log-houses 
made of wood, which in total makes 42 places for guests. The Myasnikovsky district is a territory where the culture of the Armenian, Russian and Ukrainian peoples closely intersect, combining traditions of the Don Cossackdom. Folk art occurs in abundance; it is represented by numerous professional and amateur troupes. There are two museums in the territory of the district: the Tanais Federal Museum-Reserve - devoted to ancient history of the Don, and the Heritage Museum of the Myasnikovsky District - devoted to history of the Don Armenian.

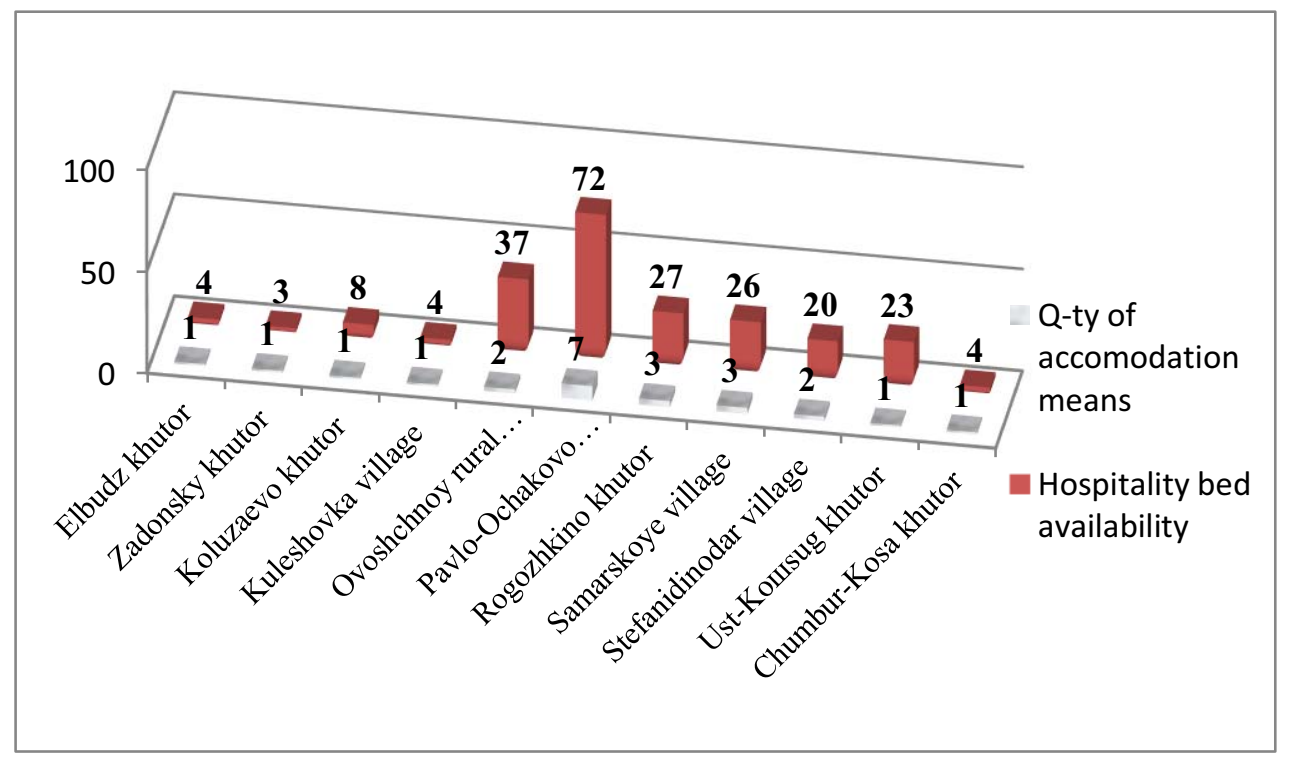

Fig. 2. The main indicators of rural accommodation means in the Azov district of the Rostov Region

Nature, climate, history, culture and traditional cuisine of the Pryazovia promote the tourism development.Guests of the Azov district are attracted by the Don Delta, the Alexander's forest, located in a forest reservation in the Azov steppes and representing a rare ecological zone of the Rostov region.Hotels and recreation centers in the Azov district are ready to accommodate people with various income levels. The only five-star hotel in the Rostov region "Old House Resort \& Spa" is located on the picturesque bank of the Don River, literally a 30-minute drive from the center of Rostov-on-Don (Ust-Koisugkhutor, Azov district). The hotel is a part of the Province Hotels network and the City Village Rostov Bath Residence. 23 comfortable rooms, a restaurant, an outdoor pool, a bath complex, a spa complex, a yacht pier are at guests' disposal.As additional services, the hotel offers car and water excursions on a comfortable boat. Moreover, the hotel arranges fishing and hunting trips for those who wish.

The Ust-Donetsky district is a unique historical and natural complex.Still-standing kurins and churches, unique natural monuments - wild steppes, ravine forests, clearest waters and springs, picturesque spurs of the Donetsk Range - give a perfect opportunity to enter into the spirit of the Cossack Outlaws.From year to year, lovers of calm, meditative rest and advocates of active communication with nature come here - fishermen, mushroom pickers, and archaeologists. The rich heritage of the Don Cossackdom has made the Ust-Donetsky district one of the centers of culture-related tourism and recreation in the Rostov region.In the territory of the Ust-Donetskydistrict there are five specially protected natural areas of regional significance: Vlasov's gully, Razdorskie slopes, Kundryuchenskie sands, Ogiburochishche, Golden Gorki.Razdorskaya and Melikhovskaya are famous for their spring water; Pukhlyakovskykhutor and Ust-Bastryanskayastanitsa have medicinal water wells. Wines produced in wineries of the Ust-Donetsk district are widely known in the Don 
and beyond.There are numerous recreation centers and guest houses on picturesque banks of the rivers. The Pukhlyakovsky Cossack Stan tourist complex located on banks of the Don River is an opportunity to get an insight into the history of the Don Region, the economic and everyday life, the peculiarities of the life of the Don Cossacks. A large courtyard with all services - sheds, a summer kitchen, a smithy, a guest house "Fishman's Kuren" and others, where the Cossack way of life has been reconstructed, will allow you to delve into the atmosphere of the Cossacks of the late 19th and early 20th centuries.

The unique ethnic archaeological complex "The Lost World" invites guests not only to relax, but to immerse themselves in a world that goes back millennia.A fascinating journey into the past on the "Path of History" will take you to the Stone and Bronze Ages. Guests are invited to visit huts, sanctuaries and workshops of primitive people, and in the ancient burial mound to join the mysteries of rituals and beliefs of our remote ancestors. Interactive programs will help you master skills and abilities of ancient hunters, fishermen, nomads.Here you will be taught how to make ancient tools and use them, to shape pots and cut bones, to paint with natural colors and dress skins, to shoot a bow and throw a spear, and also to make fire by friction - as our ancestors did millennia ago.The Lost World is not only a historical and archaeological reconstruction, but also a place of civilized recreation. Barbecue grills, arbors on the shore of the pond, playgrounds for volleyball and basketball, badminton and other sports entertainment, as well as a library, a shop, a sauna are at guests' disposal.

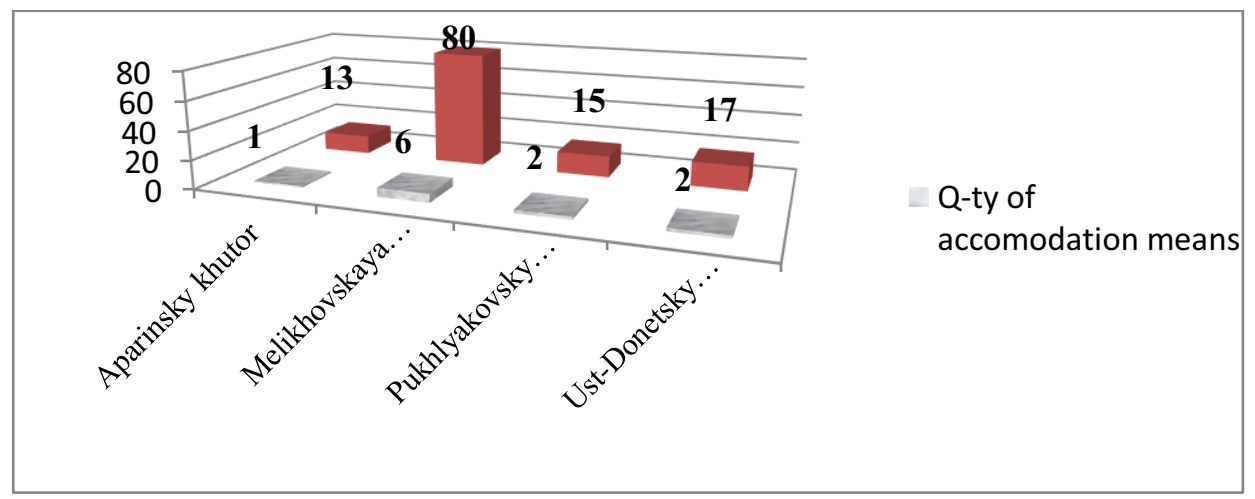

Fig. 3. The main indicators of rural accommodation means in the Ust-Donetsky district of the Rostov region

The study showed that the analyzed territories have unique climatic, cultural and historical features that create preconditions for the development of rural tourism. The UstDonetsky district has the most complete range of tourist resources.Most of sightseeing attractions of the region are located in the Razdorskayastanitsa and Pukhlyakovskykhutor. So, in the old capital of the Don land, many Cossack houses, kurins, trade and household buildings have been preserved, and there is also an operating ethnographic museum-reserve.

In Pukhlyakovsky, two ethnographic complexes, an art gallery and the Don Viticulture Museum were established.There is also a rich architectural heritage of the Cossack times in the khutor. Today, in the Ust-Donetsky district there are 35 tourist accommodation means, of which 11 are rural.

The increasing rural hotel room capacity, the expansion of the list of additional services of operational rural hotels, the development of new tourist routes and excursion programs will increase the socio-economic indicators of rural tourism and the hospitality industry in the analyzed districts that already have the basic infrastructure for the development of the rural tourism and hospitality industry. On the model of the analyzed districts, it is necessary to expand the tourist infrastructure in order to develop rural tourism in rural settlements remote from urbanized areas. 
A number of factors that have downward pressure on the development of rural tourism in the Rostov region:poor roads, poor negotiability, high fares, high service prices; lack of information, advertising, marketing, promotion; poorly developed infrastructure, lack of trained personnel; insufficient number of accommodation means; weak state support, insufficient attention of the authorities, lack of funding; a large share of the grey market; weak cooperation; insufficient work of the authorities with the rural population. Therefore, it is necessary to develop a Program for the Development of Rural Tourism in the Rostov region, which will promote its various types, describe the procedure for organizing and functioning of rural accommodation means, the technology for booking rural guest houses, transporting and accommodation of guests, providing them with additional services.Arrangement of functioning of rural accommodation means will raise the possibility of cooperation with establishments, specialist providers of services, and not-for-profit organizations and establishments related to their activity and directly or indirectly related to rural tourism.

The strategic goals for the development of rural tourism in the Rostov regionare illustrated in Figure 4, and the expansion of agritourism itself should be based on the integrated management of rural areas, indicative planning and target programming.

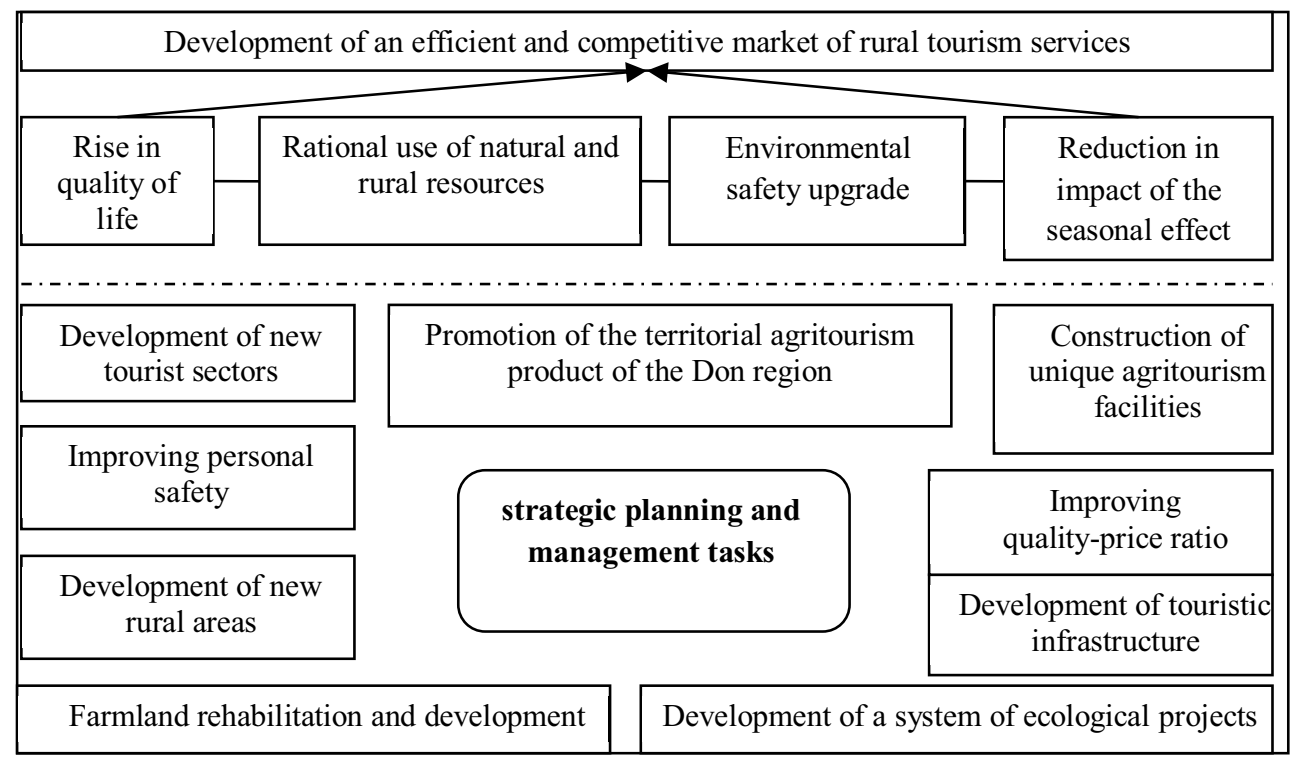

Fig. 4. Strategic objectives in development of a rural tourism industry

Within the framework of the rural tourism development strategy, management can be arranged according to the model shown in Figure 5. 


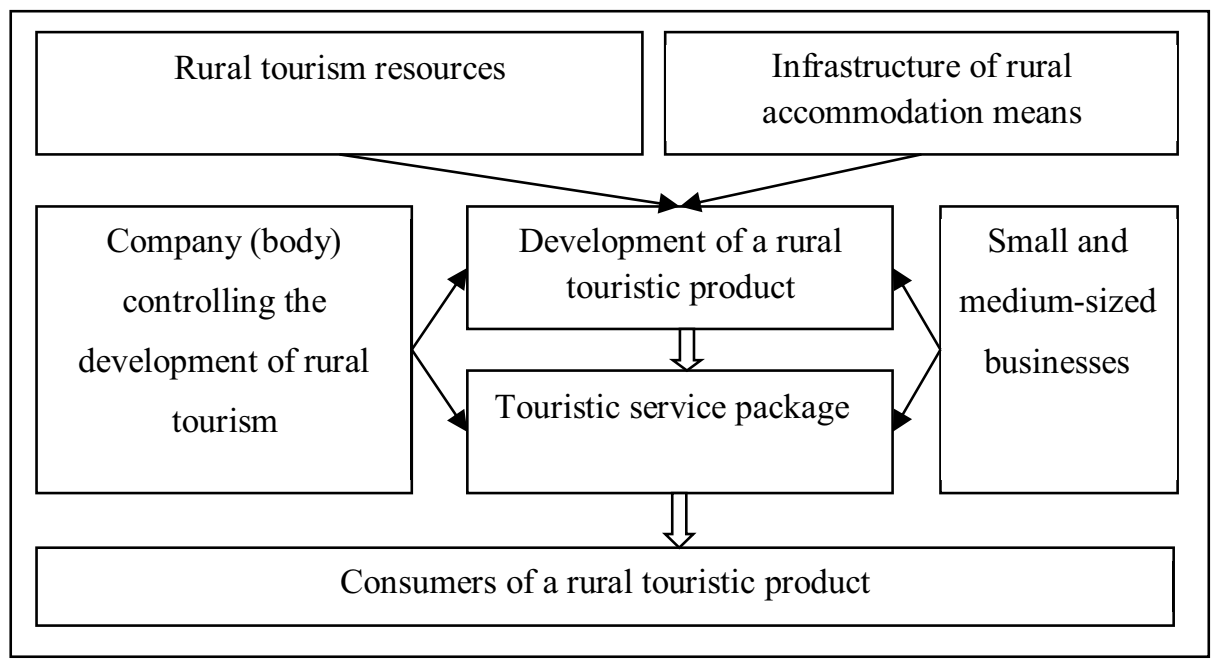

Fig. 5. Model of rural tourism development management

For pioneers of rural tourism, each stanitsa or khutor in the Don region can become a source of inspiration. One of the most important sphere in the work of the administrative apparatus of districts is the intensive development of the recreation and tourism industry, the creation of conditions for civilized recreation by arranging beaches, building parking lots, modern accommodation means (mini-hotels, tourist complexes), catering establishments, sports facilities, developing new tourist routes and excursion service programs. And the social and economic effect of the development of rural tourism in remote, depressed areas can be determined by applying the methodology for estimation of the rural tourism industry performance.

\section{Discussion}

Prospects of rural tourism in the territories of the Rostov regionshould be considered with regard to their social and economic efficiency.The tourism industry is one of the most profitable sectors of the world economy and plays an important and sometimes the main role in drawing up the gross domestic product, strengthening the balance of trade, and providing employment opportunities.Impact of rural tourism on the economy of the Don region will be direct or indirect.A direct impact will arise in the process of spending by tourists in the region of residence.Tourist money will stay in the region and increase its income, i.e. a chain of "expenses-income-expenses" will arise, and so on.In the course of cycling of tourist expenses in the economy of the Don region, an indirect impact, or "multiplier effect" will come into force.Tourist money will begin to work for the regional economy at the moment of payment for tourist services. Service providers will use this money to pay their employees, who will spend it to pay for services, goods, etc. At each stage of the provision of services, tax payments will be made to regional treasuries, which subsequently will enable representatives of regional authorities to apply funds received forward financing the social sphere of the region. The rural tourism sector has a significant synergistic effect, both for related industries, and for the social and economic development of the territory of localization of tourism industry enterprises.In modern times, the development of rural tourism, driven by general laws of economic development, is the development of partnership between the state, economy and science. The development of rural tourism is a fairly new way to renovate sectors of the economy; therefore, the problem to estimate its socio-economic performance 
is relevant.Figure 6 shows the comprehensive methodology for estimation of the rural tourism industry performance.

\begin{tabular}{|l|}
\hline \multicolumn{1}{|c|}{ Methodology for estimation of the rural tourism industry performance } \\
\hline Estimation of the rural tourism industry in the economy of the Rostov Region \\
\hline Estimation of traveler attractions' localization \\
\hline Estimation of social efficiency of the agritourismindustry's functioning \\
\hline Estimation of balance of income and expenditure for the touristic industry \\
\hline Expert estimation technique on a three-point scale \\
\hline Implementation of innovative projects \\
\hline Increase in the economic performance of the rural tourism industry \\
\hline \begin{tabular}{l} 
Links and interactions between touristic service providers \\
\hline Geographic proximity of participants in the agritourism industry
\end{tabular} \\
\hline $\begin{array}{l}\text { Quantitative methodology for estimating performance of participants of the } \\
\text { rural tourism industry according to the synergistic approach }\end{array}$ \\
\hline $\begin{array}{l}\text { Estimating performance of providers of services for the rural tourism industry (scope } \\
\text { of rendered services, company valuation, returns on assets, profitability, etc.) }\end{array}$ \\
\hline
\end{tabular}

Fig. 6. shows the methodology for estimation of the rural tourism industry performance

Analysis of the rural tourism industry performance should be started with estimation of contribution to the regional economy.The role of the development of the rural tourism industry in the regional economy can be estimated using various indicators shown in Figure 6.An analysis of the target performance of the rural tourism industry should be based on the adjustment ratio calculation, taking the projected and actual effects from the development of the tourism industry into account.

$$
k=(E a / E p-1) 100 \%
$$

where $E a$ - actual effect;

$E p$ - project effect.

Zero adjustment ratio indicates the most effective adjustment between the actual performance of the agritourism industry and the projected one; negative adjustment ratio indicates insufficient projected effect; positive adjustment ratio indicates overachievement of the target.Integration processes taking place in rural tourism result in the origin of a synergistic effect, which is characterized by the excess of amounts of income from the joint functioning of industry participants over the income of the same enterprises from individual functioning. 
Thus, it is possible to quantify the functioning of participants in the rural tourism industry according to the synergistic approach, using a methodology for comparing the resulting performance indicators of the same participants before and after.

\section{Conclusions}

Analysis of studies in the field of enterprises' functioning in the rural tourism industry of the Rostov regionhas shown that the further development of the industry can become a growth area for the social and economic development of both rural areas and the Don region as a whole.Geographic and infrastructural growth of rural tourism in the Rostov Region will contribute to its further development.Rural tourism is able to be a modern and effective factor in the development of territories and to enrich rural population, especially in depressed areas of the region. In conclusion, it should be noted that:

1.Development potential of the Don rural tourism and hospitality industry should be addressed through the lens of its social and economic efficiency, which can be estimated using the methodology for estimation of the rural tourism industry performance.

2.The rural tourism development will provide for the motivation to improve living conditions of rural residents, enrich them with support of their own resources of household, and heighten the interest in interaction of neighbors for village housekeeping.

3.The rural tourism development will induce investments, innovative projects implementation and, as a result, the social infrastructure development.

4.A significant social effect from the development of rural tourism infrastructure will be evidenced in creation of employment opportunities for rural population, a rise in living standards in rural regions due to an increase in the income of rural residents and an increase in local treasuries' incomes, the development of small business in rural areas, which will make it possible to preserve the traditional way of life and to reduce the drift of young people from the land.All this will contribute to the solution of important social and economic problems of the rural areas of the Rostov Region.

\section{References}

1. T.N. Songkhla, Discourse journal of agriculture and food sciences 4(1), 54-67 (2013)

2. H.A.M. Shaffril, A. Hamzah, S.Md. Yassin, B.A. Samah, J.L. D’Silva, N. Tiraieyari, M. Muhammad, Asia Pacific journal of tourism research 3(20), 295-313 (2015)

3. G.O. Hossein, H. Alipour, S. Dalir, Journal of sustainable development studies 1(6), 4863 (2014)

4. F. Leco, J.M. Hernández, A.M. Campón, International journal of environmental research 1(7), 255-264 (2012)

5. C.K. Ayhana, T.C. Taşlıa, F. Ozkokb, H. Tatlıc, Tourism Management 76, 103949 (2020)

6. L.S. Sidali, A. Spiller, B. Schulze, Food, Agri-Culture and Tourism:Linking Local Gastronomy and Rural Tourism: Interdisciplinary Perspectives, 197 (2011)

7. O. Paresishvili, L. Kvaratskhelia, V. Mirzaeva, Annals of Agrarian Science 15(3), 344348 (2017)

8. B. Lane, E. Kastenholz, Journal of Sustainable Tourism 23(8-9), 1133-1156 (2015)

9. L. M. Lun, H. Pechlaner, M. Volgger, Journal of Quality Assurance in Hospitality \& Tourism 17(4), 389-411 (2016)

10. A. Farmaki, Tourism management perspective 3(2), 72-78 (2012) 
11. J.A. Pesonen, Tourism and Hospitality Management 1(18), 69-82 (2011)

12. R.M. Torres, J.H. Momsen, Tourism and Agriculture New Geographies of Consumption, Production and Rural Restructuring, 240 (2011)

13. N.A. Zaitseva, I.V. Goncharova, M.E. Androsenko, International Journal of Economics and Financial Issues 6(1), 288-293 (2016)

14. N.A. Zaitseva, Middle East Journal of Scientific Research 3(14), 328-334 (2013)

15. N.Y. Goryushkina, D.V. Shkurkin, A.S. Petrenko, S.Y. Demin, N.S. Yarovaya, International Review of Management and Marketing 6(S6), 207-213 (2016)

16. L.N. Kazmina, V.S. Makarenko, V.V. Provotorina, T.N. Grigorenko, International Journal of Economics and Business Administration 7, 510-520 (2019) doi:10.35808/ijeba/297

17. L.N. Kazmina, V.V. Provotorina, Humanities and socio-economic Sciences 5(96), 109114 (2017)

18. V.V. Provotorina, L.N. Kazmina, A.S. Petrenko, G.E. Ekinil, E3S Web of Conferences 175, 10002 (2020) doi:10.1051/e3sconf/202017510002

19. L.N. Kazmina, V.S. Makarenko, V.V. Provotorina, E.M. Shevchenko, E3S Web of Conferences 175, 10001 (2020) doi:10.1051/e3sconf/202017510001

20. V.V. Provotorina, L.N. Kazmina, A.S. Petrenko, V.S. Makarenko, Proceedings of the XIII International Scientific Conference on Architecture and Construction 2020.Lecture Notes in Civil Engineering, 20-32 Springer, Singapore 130 (2020) https://doi.org/10.1007/978-981-33-6208-6_3

21. S. Wang, K. Hung, International Journal of Hospitality Management 48, 92-101 (2015) 